\title{
Seroprevalence and associated factors of infectious bovine rhinotracheitis and bovine viral diarrhea in dairy cows in the Caparaó region, Espírito Santo, Brazil
}

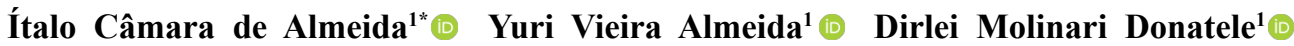 Renata Cogo Clipes $^{2}$ (D) Graziela Barioni ${ }^{1}$ (i) Marcos Santos Zanini $^{1}$ (D) Paula Alessandra Di Filippo ${ }^{3}$ (D)}

${ }^{1}$ Departamento de Medicina Veterinária, Universidade Federal do Espírito Santo (UFES), 29500-000, Alegre, ES, Brasil. E-mail: almeidaicvet@gmail.com. ${ }^{*}$ Corresponding author.

${ }^{2}$ Instituto Federal do Espírito Santo (IFES), Alegre, ES, Brasil.

${ }^{3}$ Departamento de Medicina Veterinária, Universidade Estadual do Norte Fluminense Darcy Ribeiro (UENF), Campos dos Goytacazes, RJ, Brasil.

ABSTRACT: This study evaluated the seroprevalence and associated factors of Infectious Bovine Rhinotracheitis (IBR) and Bovine Viral Diarrhea (BVD), and to analyze the possible relationship between IBR, BVD, and the occurrence of mastitis. For this purpose, 854 crossbred dairy cows were evaluated from 69 properties allocated in the 12 municipalities that make up the Caparaó region, Espirito Santo (ES), Brazil. The seroprevalence of IBR and BVD was determined using the indirect ELISA test. Associations between variables were estimated using the prevalence ratio $(P R)$ with a $95 \%$ confidence interval. The chi-square test was used to verify the significance of the associations ( $P<0.05)$. The average prevalence of IBR and BVD was $48.59 \%$ and $26.46 \%$, respectively. Animals seroreactive for IBR were more likely to develop subclinical mastitis $(P<0.01 ; P R: 1.27)$, and cows that were seroreactive for BVD were more likely to develop clinical mastitis $(P<0.01$; $P R:$ 2.24). Mechanical milking was considered a factor associated with IBR $(P<0.01 ; P R: 1.36)$ and BVD $(P<0.01 ; P R: 1.25)$. Reproductive management by natural breeding was considered a factor associated with IBR $(P<0.01 ;$ PR: 1.22). Animals seroreactive for BVD were more likely to develop reproductive problems $(P<0.01 ; P R: 1.34)$. It was concluded that the agents that cause IBR and BVD are widely disseminated in dairy cattle herds in the municipalities of the Caparaó region, ES, Brazil. The presence of IBR and BVD increased the chances of cows developing subclinical mastitis and clinical mastitis, respectively, and the cows that were mechanically milked were more likely to be seroreactive for IBR and $B V D$.

Key words: $B V D$, crossbred cow, dairy cows, indirect ELISA, IBR, mastitis.

\begin{abstract}
Soroprevalência e fatores associados à rinotraqueíte infecciosa bovina e diarreia viral bovina em vacas leiteiras na região do Caparaó, Espírito Santo, Brasil
\end{abstract}

RESUMO: $O$ objetivo do presente estudo foi avaliar a soroprevalência e os fatores de risco associados à Rinotraqueite Infecciosa Bovina (IBR) e Diarreia Viral Bovina (BVD), e analisar a possivel relação entre IBR, BVD e à ocorrência de mastite. Para tanto, foram avaliadas 854 vacas leiteiras mestiças de 69 propriedades localizadas nos 12 municipios que compõem a região do Caparaó, Espírito Santo (ES), Brasil. A soroprevalência de IBR e BVD foram determinadas pelo teste ELISA indireto. As associações entre variáveis foram estimadas pela razão de prevalência (PR) com intervalo de confiança de $95 \%$. O teste do qui-quadrado foi utilizado para verificar a significância das associações ( $P$ $<0,05)$. A prevalência média de IBR e BVD foi de $48 \%$ e 26\%, respectivamente. Os animais sororreagentes para IBR foram mais propensos a desenvolver mastite subclínica $(P<0,01 ; P R: 1,27)$, e as vacas sororreagentes para BVD foram mais propensas a desenvolver mastite clínica $(P<0,01 ; P R: 2,24)$. À ordenha mecânica foi considerada um fator associado a IBR $(P<0,01 ; P R: 1,36)$ e BVD $(P<0,01 ; P R$ : 1,25). O manejo reprodutivo por monta natural foi considerado um fator associado $I B R(P<0,01 ; P R$ : 1,22$)$. Os animais sororreagentes para $B V D$ foram mais propensos a desenvolverem problemas reprodutivos $(P<0,01 ; P R: 1,34)$. Concluiu-se que os agentes causadores de IBR e BVD estão amplamente disseminados em rebanhos leiteiros nos municípios da região de Caparaó, ES, Brasil. A presença de IBR e BVD aumentaram as chances das vacas desenvolverem mastite subclínica e mastite clínica, respectivamente, e as vacas que foram ordenhadas mecanicamente apresentaram maior probabilidade de serem sororreagente para IBR e BVD.

Palavras-chave: BVD, ELISA indireto, IBR, mastite, vacas mestiças, vacas leiteiras.

\section{INTRODUCTION}

The Caparaó region, located in the southern part of the Brazilian state of Espírito Santo, is an important milk production region and is home to approximately $14 \%$ of the total dairy production in
Espírito Santo (IBGE, 2019). Despite the expansion of the dairy industry in the region, there are still few official animal health programs, and large productive losses can be related to infectious diseases, such as Infectious Bovine Rhinotracheitis (IBR) and Bovine Viral Diarrhea (BVD), caused by the agents Bovine 
Herpesvirus Type 1 (BHV-1) and Bovine Viral Diarrhea Virus (BVDV), respectively (CAN et al., 2016). Even though these diseases are better known due to the reproductive disorders observed in affected animals (STRAUB, 2001; WERNICKI et al., 2015), they affect cattle worldwide, causing significant economic losses due to decreased performance and milk yield, as well as increased risk of morbidity and mortality (CAN et al., 2016).

The seroprevalence of IBR can vary drastically according to geographic region, with a prevalence of $35 \%$ in Belgium (BOELAERT et al., 2000), 77\% in Italy (RINALDI et al., 2007), 69\% in England (PATON et al., 1998), 37\% in Uruguay (GUARINO et al., 2008), and 51\% in Peru (STAHL et al., 2002). In Brazil, various studies have reported a seroprevalence of IBR of $83 \%$ in Goiás (VIEIRA et al., 2003), 68\% in São Paulo (JUNQUEIRA et al., 2006), and 58\% in Minas Gerais (ROCHA et al., 2001). Only one previous study exists in the state of Espírito Santo, finding an average prevalence of $66 \%$, evaluating neutralizing antibodies (SANTOS et al., 2014).

BVD is distributed worldwide, and its seroprevalence is estimated to range between $46 \%$ and 78\% (RICHTER et al., 2019). In Brazil, several serological studies have demonstrated a wide distribution and high prevalence rate in several states, as follows: Bahia, 56\% (NORONHA et al., 2001); Paraíba, 39\% (FERNANDES et al., 2016); Goiás, 54\% (BRITO et al., 2010); Minas Gerais, 61\% (MINEO et al., 2006); São Paulo, 56\% (SAMARA et al., 2004); Paraná, 61\% (ALFIERI et al., 2004); and Rio Grande do Sul, 58\% (SCHERER et al., 2002). However, until now, no data were reported for the state of Espírito Santo.

Economic losses due to decreased milk production are associated with IBR and BVD infection. Losses of $2.6 \mathrm{~kg}$ of milk per day in cows with subclinical IBR compared to seronegative cows have been reported in England (STATHAM et al., 2015). A study conducted in Turkey reported milk production reductions of up to $10 \%$ for animals that had detectable BHV1 (seropositive) compared with animals seronegative (CAN et al., 2016). For BVD, losses of $\$ 40$ to $\$ 95$ were estimated per infected cow in Danish herds (HOUE, 2003), and a reduction of up to $19 €$ per thousand liters of produced milk has been reported in France (FOURICHON et al., 2005). There was a decrease of up to $10 \%$ in milk production in cows with BVDV antibodies compared to negative cows (MOERMAN et al., 1994). There are reports that the immunosuppressive properties of BHV-1 and BVDV may play a secondary role in the etiology of bacterial diseases, especially mastitis (POTGIETER et al., 1984; HUTCHINGS et al., 1990; KOPPERSLALIC et al., 2001).

The objective was to conduct a crosssectional study on the seroprevalence of IBR and BVD in the Caparaó region, Espírito Santo, Brazil, and to analyze the possible relationship between these viral diseases and mastitis, as well as identifying the factors associated with management that can contribute to the transmission of IBR and BVD.

\section{MATERIALS AND METHODS}

\section{Study population}

A total of 854 clinically healthy crossbred (Bos taurus taurus $\times$ Bos taurus indicus) dairy cows in different lactation phases were used. The farms were located in the 12 municipalities that compose the Caparaó Capixaba micro-region $\left(20^{\circ} 26^{\prime} 5\right.$ " S and $41^{\circ} 47^{\prime} 2$ " W), in the southern part of Espírito Santo (Alegre, Bom Jesus do Norte, Divino de São Lourenço, Dores do Rio Preto, Guaçuí, Ibatiba, Ibitirama, Irupi, Iúna, Jerônimo Monteiro, Muniz Freire, and São José do Calçado), Brazil, and were chosen at random in the period from February 2015 to December 2015. Of the 72 farms evaluated at random, through registration with a dairy company in the region, animals from 69 farms were used (with no history of vaccination for IBR and BVD), 5 farms per municipality, except Alegre and Jerônimo Monteiro, where 9 and 10 farms were evaluated, respectively.

The sample size calculation was performed according to the following formula (DEAN et al., 2013):

$$
\mathrm{n}=\operatorname{deff} \mathrm{x} \frac{\mathrm{Npq}}{\frac{\mathrm{d}^{2}}{1.96^{2}}(\mathrm{n}-1)+\mathrm{pq}}
$$

where $n$ is the sample size, deff is the design effect, $N$ is the population size, $p$ is the estimated proportion, $q$ $=1-p$, and $d$ is the absolute precision level.

Using an anticipated frequency of $50 \%$ for the diseases (IBR and BVD), a sampling error of $5 \%$, confidence interval of $95 \%$, and herd size of 2,223,531 in Espírito Santo in 2015 (IBGE, 2019), we calculated the minimum sample size as 385 animals. A total of 854 animals were evaluated.

\section{Serological tests for infectious bovine rhinotracheitis} (IBR) and bovine viral diarrhea (BVD)

Blood samples were collected from all lactating cows, with no history of vaccination for IBR or BVD, by puncturing the coccygeal vein in a vacuum collection system. The collected blood was stored in tubes without anticoagulant, and the samples were 
centrifuged at $200 \mathrm{G}$ for 5 minutes, and the obtained serum was aliquoted in $1.5 \mathrm{~mL}$ polyethylene tubes and stored at $-80{ }^{\circ} \mathrm{C}$. The diagnostic examination for IBR and BVD was performed via an indirect enzyme-linked immunosorbent assay (ELISA) using the CIVTEST ${ }^{\circledR}$ BOVIS IBR kit (sensitivity, 85.4\%; specificity, 99.7\%; Amer, Catalonia, Spain), effective at detecting antibodies to specific antigens of Infectious Bovine Rhinotracheitis (IBRv), and the CIVTEST ${ }^{\circledR}$ BOVIS BVD/BD P80 kit (sensitivity, 96.9\%; specificity, 97.3\%; Amer, Catalonia, Spain), designed to detect antibodies against a specific protein present in all strains of BVDV (non-structural protein P80).

\section{Test for mastitis}

The presence of clinical mastitis was determined by identifying the clinical signs of inflammation of the mammary gland and by the black background mug test. In turn, subclinical mastitis was diagnosed by the California mastitis test (CMT). The animals were considered positive for clinical or subclinical mastitis when there was an alteration in the mug or California test, respectively, in at least one of the teats (COLE et al., 1965).

\section{Data analysis}

A questionnaire regarding the reuse of disposable needles, testing for brucellosis, milking type (manual/mechanical), reproductive management (artificial insemination/natural breeding), and whether the cow presented reproductive problems (abortion, estrus repetition, placental retention, and uterine infection) was answered by the owners. The farms were classified into small (up to $53 \mathrm{~L} /$ day), medium (from 54 to $133 \mathrm{~L} /$ day), and large (>133 L/day) milk producers (BARROS et al., 2001). The result of the serology for the IBR and BVD tests (positive and negative) was considered as a dependent variable and the information regarding the epidemiological questionnaire was the independent variable.

The statistical results were demonstrated by descriptive analysis. Associations between variables (univariable analysis) were estimated by the cross-product ratio (prevalence ratio, PR) and 95\% confidence interval. The chi-square test was used to verify the significance of the associations ( $\mathrm{P}$ $<0.05$ ). The calculations were performed using Epi Info 7.2 software.

\section{RESULTS}

The prevalence of IBR and BVD varied in the studied municipalities of Espírito Santo (Table 1). For IBR, we reported a mean prevalence of $48 \%(95 \%$ CI: $47.72-49.45$ ), ranging from $20 \%$ to $65 \%$, and a mean prevalence of $26 \%(95 \%$ CI: $47.74-49.43)$ for $\mathrm{BVD}$, ranging from $7 \%$ to $45 \%$.

Table 2 shows the percentage distribution of the possible variables associated with the seroprevalence of Infectious Bovine Rhinotracheitis and Bovine Viral Diarrhea in crossbred dairy cows in the Caparaó region, Espírito Santo, Brazil.

Table 1 - Seroprevalence of Infectious Bovine Rhinotracheitis (IBR) and Bovine Viral Diarrhea (BVD) analyzed with specific indirect ELISA tests on crossbred dairy cows in the municipalities of the Caparaó region in Espírito Santo, Brazil (February 2015 to December 2015)

\begin{tabular}{|c|c|c|c|c|c|}
\hline \multirow[t]{2}{*}{ Municipality } & \multirow{2}{*}{$\begin{array}{l}\text { Total number of } \\
\text { animals }\end{array}$} & \multicolumn{2}{|c|}{ 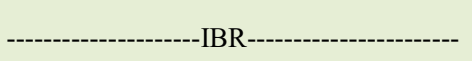 } & \multicolumn{2}{|c|}{----------------------'BVD-------------------- } \\
\hline & & Number of positives & Prevalence (\%) & Number of positives & Prevalence $(\%)$ \\
\hline Alegre & 143 & 91 & 63.63 & 58 & 40.55 \\
\hline Bom Jesus do Norte & 38 & 21 & 55.26 & 3 & 7.89 \\
\hline Divino de São Lourenço & 63 & 13 & 20.63 & 17 & 26.98 \\
\hline Dores do Rio Preto & 84 & 44 & 52.38 & 8 & 9.52 \\
\hline Guaçuí & 36 & 12 & 33.33 & 10 & 27.77 \\
\hline Ibatiba & 57 & 19 & 33.33 & 10 & 17.54 \\
\hline Ibitirama & 72 & 35 & 48.61 & 7 & 9.72 \\
\hline Irupi & 35 & 17 & 48.57 & 7 & 20.00 \\
\hline Iúna & 69 & 45 & 65.21 & 9 & 13.04 \\
\hline Jerônimo Monteiro & 137 & 66 & 48.17 & 55 & 40.14 \\
\hline Muniz Freire & 75 & 27 & 36.00 & 34 & 45.33 \\
\hline São José do Calçado & 45 & 25 & 55.55 & 8 & 17.77 \\
\hline Total & 854 & 415 & 48.59 & 226 & 26.46 \\
\hline
\end{tabular}

Ciência Rural, v.51, n.12, 2021. 
Table 2 - Percentage distribution of possible variables associated with Infectious Bovine Rhinotracheitis (IBR) and Bovine Viral Diarrhea (BVD) seroprevalence in crossbred dairy cows in the municipalities of the Caparaó region in Espírito Santo, Brazil (February 2015 to December 2015).

\begin{tabular}{|c|c|c|c|c|c|c|}
\hline Variables & n Farms & n animals & + IBR & $\%$ IBR & $+\mathrm{BVD}$ & $\% \mathrm{BVD}$ \\
\hline \multicolumn{7}{|c|}{--------------------------------------------------------------------------'Milk producers----------------------------------------------------------------------- } \\
\hline Small (up to $53 \mathrm{~L} /$ day) & 7 & 41 & 20 & 48.78 & 10 & 24.39 \\
\hline Medium (54 to $133 \mathrm{~L} /$ day) & 22 & 167 & 87 & 52.09 & 35 & 20.95 \\
\hline Large (>133 L/day) & 40 & 646 & 308 & 47.67 & 181 & 28.01 \\
\hline \multicolumn{7}{|c|}{ 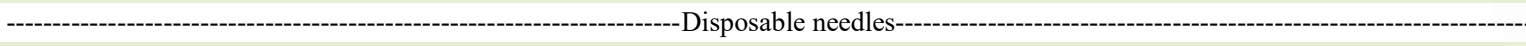 } \\
\hline Yes & 31 & 467 & 238 & 50.96 & 123 & 26.33 \\
\hline No & 38 & 387 & 177 & 45.73 & 103 & 26.61 \\
\hline \multicolumn{7}{|c|}{ 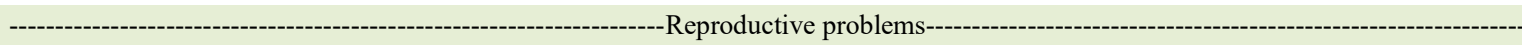 } \\
\hline Yes & 33 & 401 & 194 & 48.37 & 131 & 32.66 \\
\hline No & 36 & 453 & 221 & 48.78 & 95 & 20.97 \\
\hline \multicolumn{7}{|c|}{ - } \\
\hline Yes & 32 & 432 & 197 & 45.60 & 103 & 23.84 \\
\hline No & 37 & 422 & 218 & 51.65 & 123 & 29.14 \\
\hline \multicolumn{7}{|c|}{ 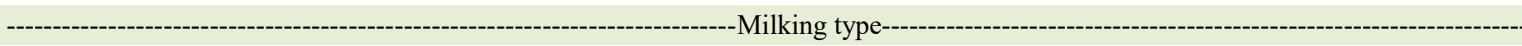 } \\
\hline Mechanical & 55 & 750 & 381 & 50.80 & 215 & 28.66 \\
\hline Manual & 14 & 104 & 34 & 32.69 & 11 & 10.57 \\
\hline \multicolumn{7}{|c|}{ 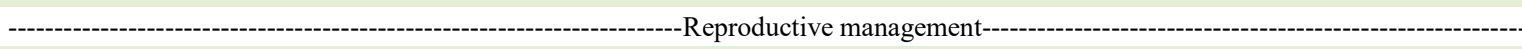 } \\
\hline Artificial insemination & 40 & 521 & 233 & 44.72 & 128 & 24.56 \\
\hline Natural breeding & 29 & 333 & 182 & 54.65 & 98 & 29.42 \\
\hline
\end{tabular}

$\mathrm{n}$ Farms $=$ number of farms evaluated; $\mathrm{n}$ animals $=$ number of animals tested; + IBR $/$ BVD $=$ animals seroreagent for Bovine Infectious Rhinotracheitis (IBR) or Bovine Viral Diarrhea (BVD); \% IBR / BVD = percentage of animals seroreagent for IBR or BVD.

We found an association $(\mathrm{P}<0.01$; PR: 1.27) between IBR and the presence of subclinical mastitis, as well as an association $(\mathrm{P}<0.01$; PR: 2.24) between BVD and the presence of clinical mastitis (Table 3). In this context, animals that were seroreactive for IBR had a higher prevalence ratio for the development subclinical mastitis, animals that were seroreactive for BVD had a higher prevalence ratio for clinical mastitis (Table 4). However, there was no association between IBR and clinical mastitis

Table 3 - Univariable analysis for factors associated with seroprevalence of Infectious Bovine Rhinotracheitis (IBR) in crossbred dairy cows in the municipalities of the Caparaó region in Espírito Santo, Brazil (February 2015 to December 2015).

\begin{tabular}{|c|c|c|c|}
\hline & Prevalence ratio & Confidence interval (95\%) & $\mathrm{p}$-value \\
\hline Clinical mastitis & 1.10 & $0.63-1.92$ & 0.84 \\
\hline Subclinical mastitis & 1.27 & $1.08-1.48$ & $0.002^{*}$ \\
\hline Natural breeding & 1.22 & $1.06-1.40$ & $0.005^{*}$ \\
\hline Mechanical milking & 1.36 & $1.17-1.59$ & $0.0007^{*}$ \\
\hline Reproductive problems & 0.99 & $0.85-1.14$ & 0.96 \\
\hline Needle reuse & 1.11 & $0.96-1.28$ & 0.14 \\
\hline Brucellosis test & 0.88 & $0.76-1.01$ & 0.08 \\
\hline Production level (small) & 1.00 & $0.55-1.83$ & 0.98 \\
\hline Production level (medium) & 1.12 & $0.88-1.41$ & 0.38 \\
\hline Production level (large) & 0.96 & $0.90-1.03$ & 0.35 \\
\hline
\end{tabular}

${ }^{*}(\mathrm{P}<0.05)$ using the chi-square test.

Ciência Rural, v.51, n.12, 2021. 
Table 4 - Univariable analysis for factors associated with seroprevalence of Bovine Viral Diarrhea (BVD) in crossbred dairy cows in the municipalities of the Caparaó region in Espírito Santo, Brazil (February 2015 to December 2015).

\begin{tabular}{|c|c|c|c|}
\hline & Prevalence ratio & Confidence interval (95\%) & p-value \\
\hline Clinical mastitis & 2.24 & $1.28-3.90$ & $0.006^{*}$ \\
\hline Subclinical mastitis & 1.07 & $0.91-1.27$ & 0.42 \\
\hline Natural breeding & 1.06 & $0.98-1.16$ & 0.13 \\
\hline Mechanical milking & 1.25 & $1.15-1.35$ & $0.0001^{*}$ \\
\hline Reproductive problems & 1.34 & $1.16-1.55$ & $0.0001^{*}$ \\
\hline Needle reuse & 0.98 & $0.79-1.23$ & 0.98 \\
\hline Brucellosis test & 0.81 & $0.65-1.02$ & 0.09 \\
\hline Production level (small) & 0.89 & $0.44-1.79$ & 0.89 \\
\hline Production level (medium) & 0.76 & $0.57-1.02$ & 0.08 \\
\hline Production level (large) & 1.07 & $0.99-1.14$ & 0.08 \\
\hline
\end{tabular}

${ }^{*}(\mathrm{P}<0.05)$ using the chi-square test.

nor was there an association between BVD and subclinical mastitis.

Natural breeding $(\mathrm{P}<0.01$; $\mathrm{PR}: 1.22)$ and mechanical milking $(\mathrm{P}<0.001$; $\mathrm{PR}$ : 1.36) were considered factors associated with animals seroreactive for IBR (Table 4). In this context, animals that go through natural breeding and are mechanically milked have higher prevalence rates for IBR when compared to animals from artificial insemination and manual milking. The presence of reproductive problems, reuse of disposable needles, brucellosis tests, and production levels was not significant $(\mathrm{P}>0.05)$.

The presence of antibodies against BVD increases the prevalence ratio of reproductive problems, and mechanical milking increases the prevalence ratio of cows being seroreactive for BVD (Table 4). There was no association between BVD and natural breeding, disposable needle reuse, the brucellosis test, or production level $(\mathrm{P}>0.05)$.

\section{DISCUSSION}

In the Brazilian state of Paraná, the prevalence of IBR in dairy cattle ranged from $47 \%$ to $99 \%$ (DIAS et al., 2013). In Espírito Santo, a prevalence of IBR of $49 \%, 62 \%, 67 \%$, and $80 \%$ was reported for the metropolitan, southern, northern, and northwestern regions, respectively. The authors also reported a high prevalence of seroreactive samples for the municipality of Alegre (90\%) (SANTOS et al., 2014), with values higher than those found in the present study. Higher seroprevalence of BVD was reported when compared to the present study. In the state of Paraíba, with
$39 \%$ (FERNANDES et al., 2016), Rio Grande do Sul (57\%; FRANDOLOSO et al., 2008), Maranhão (65\%; CHAVES et al., 2012), and Goiás (64\%; BRITO et al., 2010), as well as in beef cattle in Maranhão (66\%; BEZERRA et al., 2019).

The lack of knowledge on the part of producers regarding IBR and BVD, as well as the lack of measures that contribute to their control and elimination, favor the appearance of new cases in the herd. Factors such as the age of the animals, absence of tests at purchase, and reuse of rectal palpation gloves are measures that can contribute to the spread of the studied conditions (BARBOSA et al., 2019). Another factor that can contribute to the different seroprevalence of IBR and BVD in Espírito Santo and Brazil, is that these diseases do not yet have specific legislation, despite notification to the official veterinary service being mandatory, with vaccination being optional. This is unlike foot-andmouth disease and bovine brucellosis, where there is specific legislation for the control and eradication, and vaccination of animals.

One factor that could be related to IBR, $\mathrm{BVD}$, and the presence of mastitis (Table 3 and 4) would be the immunosuppressive properties of BHV-1 and BVDV, which play a secondary role in the etiology of bacterial diseases (POTGIETER et al., 1984; HUTCHINGS et al., 1990; KOPPERS-LALIC et al., 2001). Previous studies have isolated BHV-1 from mastitis milk samples, which were negative for bacterial culture; however, the evidence that the virus caused mastitis was only circumstantial (ROBERTS et al., 1974). Similarly, there have been reports of increased cases of mastitis in herds with increased 
titers of antibodies for BVDV, but the role played by BVDV in these mastitis cases is unclear (NISKANEN et al., 1995; WAAGE, 2000; WELLENBERG et al., 2002). That is, there is a lack of knowledge regarding the actual impact of the virus on cow udder health, and there is insufficient evidence on the effect of BHV-1 and BVDV infection on mastitis. However, immunosuppression caused by viral diseases can be considered a triggering factor for the onset of mastitis since there is no specific treatment for animals with IBR and BVD, and the animals will be virus carriers for the rest of their productive life.

In the present study, mechanical milking was considered a factor associated with IBR (Table 3) and BVD (Table 4). Corroborating the present study, a similar result was reported in Minas Gerais for both diseases (BARBOSA et al., 2019). It is widely reported that BHV-1 and BVDV are excreted in the milk of infected cows (WAAGE, 2000; WELLENBERG et al., 2002) and therefore deficiencies in management, udder health, and inadequate disinfection and maintenance of mechanical milking equipment can be considered factors that help in the transmission of IBR and BVD.

Animals from reproductive management by natural breeding increased the prevalence ratio for IBR (Table 3). Similar results were also found by other authors (ROCHA et al., 1999; DIAS et al., 2013; BARBOSA et al., 2019). The foreskin mucosa and urethra are sites of viral replication, meaning that a seroreactive bull may be responsible for spreading the disease within the herd (VAN DER ENGELENBURG et al., 1993). Therefore, it is important that the entire herd be tested for IBR in farms where natural breeding occurs (29 of the 69 farms evaluated), especially when bulls are used for breeding, in order to prevent the transmission of the disease to healthy animals.

There was no association between reproductive management by natural breeding and BVD (Table 4). A similar result was also reported by other authors (TADESSE et al., 2019). Unlike in the present study, in a previous study, an association between natural breeding and BVD was reported in which the bull used for breeding was considered a factor associated with the disease. The same authors reported that the use of artificial insemination could be considered a form of infection control (CHAVES et al., 2012).

There was no association between the presence of reproductive problems and IBR (Table 3). Of the 69 evaluated farms, $33(47.82 \%)$ reported reproductive problems (Table 2), with abortion (16), estrus repetition (8), placental retention (5), and uterine infection (4) being the most cited. Corroborating the present study, no associations were found between IBR and reproductive signs or cases of abortion (BARBOSA et al., 2005; BEZERRA et al., 2012). However, the presence of BVD was considered a factor associated with reproductive problems, that is, in farms with animals seroreactive for BVD, here was a higher prevalence rate of reproductive problems (Table 4). The association between estrus repetition and BVDV has also been reported by other authors (TADESSE et al., 2019). In this context, an association was also reported between the occurrence of abortion and BVD, but the authors could not state whether it was an associated risk factor since the confidence interval ranged from 0.88 to 1.22 (BRITO et al., 2010). However, unlike in the present study, no association was found between the presence of reproductive problems (abortion) and BVDV, but the authors reported a higher prevalence of BVD in properties where abortion or reproductive problems occurred (CHAVES et al., 2012; MARQUES et al., 2016; BEZERRA et al., 2019).

There was no association between IBR and BVD and the test for brucellosis, production level, and reuse of disposable needles. It was expected that the reuse of disposable needles would be a factor associated with IBR and BVD since this has been reported to be associated with other infectious, contagious diseases such as Bovine Enzootic Leukosis (ALMEIDA et al., 2021; VÁSQUEZ et al., 2016). However, these same authors also reported no association between the reuse of disposable needles and the presence of IBR.

It is important to highlight that studies that evaluate the incidence are more reliable in the association of risk factors, because the prevalence, assessed in the present study, is a combination of incidence and duration of the disease, being, therefore, more difficult to determine the causes of the risk factors. However, actions such as diagnosis, prevention, and reduction of herd exposure to infectious diseases, such as IBR and BVD, contribute to animal health and the proper functioning of the immune system, thus minimizing economic losses in the production system. However, several factors affect the productive and reproductive efficiency of cattle, especially the occurrence of such diseases in the herd. Therefore, the exposure of the herd to infectious diseases should be minimized so that they can provide greater profitability to the producer. Additional studies are needed to verify the progress of BHV-1 and BVDV in the region, as well as the molecular diagnosis for 
the detection of persistently infected animals for BVDV, one made that the ELISA test performed is not able to detect the infection in such animals.

\section{CONCLUSION}

It can be concluded that the prevalence of IBR and BVD are high in dairy cattle herds in the municipalities of the Caparaó region in Espírito Santo, Brazil, and measures for the control of IBR and BVD must be considered since an association was found between such viral diseases and mastitis and reproductive problems.

\section{BIOETHICS AND \\ BIOSSECURITY COMMITTEE APPOVAL}

The project was approved by the Committee for Ethics in Animal Use of the Federal University of Espírito Santo (UFES), under protocol number 008/2018.

\section{ACKNOWLEDGMENTS}

This study received support from the Fundação de Amparo à Pesquisa e Inovação do Espírito Santo (FAPES, process 130/2019) and Coordenação de Aperfeiçoamento de Pessoal de Nível Superior - Brazil (CAPES). Facilities were provided by Universidade Federal do Espírito Santo (UFES) and Universidade Estadual do Norte Fluminense Darcy Ribeiro (UENF).

\section{DECLARATION OF CONFLICT OF INTEREST}

We certify that there is no conflict of interest with any organization regarding the material discussed in the manuscript.

\section{AUTHORS' CONTRIBUTIONS}

The authors contributed equally to the manuscript.

\section{REFERENCES}

ALFIERI, A. F. et al. G and P genotypes of group A rotavirus strains circulating in calves in Brazil, 1996-1999. Veterinary Microbiology, v.99, n.3-4, p.167-173, 2004. Available from: $\quad<$ https://www.sciencedirect.com/science/article/pii/ S0378113503004255?via\%3Dihub>. Accessed: Nov. 18, 2019. doi: $10.1016 /$ j.vetmic.2003.10.029.

ALMEIDA, I. C. et al. Seroprevalence and influence of bovine leukemia virus on the incidence of mastitis in dairy herds. Acta Scientiae Veterinariae, v.49, n.1, p.1-8, 2021. Available from: $\quad<$ https://seer.ufrgs.br/ActaScientiaeVeterinariae/article/ view/109458>. Accessed: Jan. 31, 2021. doi: 10.22456/16799216.109458

BARBOSA, A. C. V. C. et al. Seroprevalence and risk factors to the infectious by bovine herpesvirus type $1(\mathrm{BHV}-1)$ in Goiás State, Brazil. Ciência Rural, v.35, n.6, p.1368-1373, 2005.
Available from: <https://www.scielo.br/scielo.php?pid=S010384782005000600022\&script $=$ sci_abstract $>$. Accessed: Nov. 19, 2019. doi: 10.1590/S0103-84782005000600022.

BARBOSA, V. M. et al. Risk factors associated with viral infections (BoHV-1 and BVDV) in crossbreed dairy herds with reproductive failures, Uberlândia, MG. Arquivo Brasileiro de Medicina Veterinária e Zootecnia, v.71, n.4, p.1243-1250, 2019. Available from: $<$ https://www.scielo.br/scielo.php?script=sci artte xt\&pid=S0102-09352019000401243 > . Accessed: Mar. 05, 2020. doi: $10.1590 / 1678-4162-10326$.

BARROS, G. S. A. C. et al. 2001. Sistema agroindustrial do leite no Brasil. Brasília: Embrapa Informação Tecnológica, 2001. 172p. Available from: <https://www.scielo.br/ scielo.php?script $=$ sci_nlinks\&ref $=000097 \&$ pid $=$ S 0100 204X200600010002100001\&lng=en>. Accessed: Feb. 18, 2019.

BEZERRA, D. C. et al. Prevalence and risk factors associated with infection by bovine herpesvirus type 1 in dairy cattle in the state of Maranhão. Revista Brasileira de Ciências Veterinárias, v.19, n.3, p.158-162, 2012. Available from: <http://periodicos.uff.br/ rbcv/article/download/6903/5186>. Accessed: Oct. 18, 2019. doi: 10.4322/rbcv.2014.099

BEZERRA, N. P. C. et al. Risk factors analysis applied to antibodies to Bovine Herpesvirus Type 1, Bovine Viral Diarrhea Virus, Bovine Leukemia Virus and Brucella abortus among cattle: a cross-sectional study. Acta Veterinaria Brasilica, v.13, n.1, p.5-12, 2019. Available from: <https://periodicos.ufersa.edu.br/ index.php/acta/article/view/7818>. Accessed: Nov. 18, 2019. doi: 10.21708/avb.2019.13.1.7818.

BOELAERT, F. et al. Prevalence of bovine herpesvirus-1 in the Belgian cattle population. Preventive Veterinary Medicine, v.45, n.3-4, p.285-295, 2000. Available from: <https://www.ncbi. nlm.nih.gov/pubmed/10821966>. Accessed: Nov. 19, 2019. doi: 10.1016/S0167-5877(00)00128-8.

BRITO, W. M. E. D. et al. Prevalência da infecção pelo vírus da Diarreia Viral Bovina (BVDV) no estado de Goiás, Brasil. Revista de Patologia Tropical, v.39, p.7-19, 2010. Available from: $<$ https://www.revistas.ufg.br/iptsp/article/viewFile/9494/6570>. Accessed: Nov. 18, 2019. doi: 10.5216/rpt.v39i1.9494.

CAN, M. F. et al. Estimation of production and reproductive performance losses in dairy cattle due to bovine herpesvirus 1 (BoHV1) infection. Veterinarski Arhiv, v.86, n.4, p.499-513, 2016. Available from: <https://hrcak.srce.hr/file/244568>. Accessed: Nov. 19, 2019.

CHAVES, N. P. et al. Frequency and factors associated with bovine viral diarrhea virus infection in nonvaccinated dairy cows in the state of Maranhão, Brazil. Arquivos do Instituto Biológico, v.79, n.4, p.495-502, 2012. Available from: <http://www.scielo.br/pdf/ aib/v79n4/a05v79n4.pdf>. Accessed: Nov. 19, 2019.

COLE, E. J. et al. Detection efficiency of mastitis screening tests. Journal of Food Protection, v.28, n.1, p. 5-8, 1965. Available from: $<$ https://meridian.allenpress.com/jfp/article/28/1/5/424533>. Accessed: Apr. 04, 2020. doi: 10.4315/0022-2747-28.1.5.

DIAS, J. A. et al. Seroprevalence and risk factors of bovine hespesvirus 1 infection cattle herds in the State of Paraná, Brazil. Transboundary and Emerging Diseases, v.60, n.1, p.39-47, 2013. Available from: <https://www.ncbi.nlm.nih.gov/

Ciência Rural, v.51, n.12, 2021. 
pubmed/22364224>. Accessed: Nov. 20, 2019. doi: 10.1111/j.1865$1682.2012 .01316 \mathrm{x}$

FERNANDES, L. G. et al. Herd-level prevalence and risk factors for bovine viral diarrhea virus infection in cattle in the State of Paraíba, Northeastern Brazil. Tropical Animal Health and Production, v.48, n.1, p.157-165, 2016. Available from: <https:// link.springer.com/article/10.1007/s11250-015-0937-x>. Accessed: Apr. 04, 2020. doi: 10.1007/s11250-015-0937-x.

FOURICHON, C. et al. Quantification of economic losses consecutive to infection of a dairy herd with bovine viral diarrhoea virus. Preventive Veterinary Medicine, v.72, n.1-2, p.177-181, 2005. Available from: <https://www.ncbi.nlm.nih.gov/ pubmed/16162364>. Accessed: Nov. 21, 2019. doi: 10.1016/j. prevetmed.2005.08.018

FRANDOLOSO, R. et al. Prevalence of enzootic bovine leukosis, bovine viral diarrhea, infectious bovine rhinotracheitis and bovine neosporosis in 26 dairy cattle farms from the northeast region of Rio Grande do Sul, Brazil. Ciência Animal Brasileira, v.9, n.4, p.1102-1106, 2008. Available from: <https://www.revistas.ufg.br/ vet/article/view/1398>. Accessed: Nov. 21, 2019.

GUARINO, H. et al. Prevalence of serum antibodies to bovine herpesvirus-1 and bovine viral diarrhea virus in beef cattle in Uruguay. Preventive Veterinary Medicine, v.85, n.1-2, p.34-40, 2008. Available from: <https://www.ncbi.nlm.nih.gov/ pubmed/18280598>. Accessed: Nov. 18, 2019. doi: 10.1016/j. prevetmed.2007.12.012.

HOUE, H. Economic impact of BVDV infection in dairies. Biologicals, v.31, n.2, p.137-143, 2003. Available from: <https:// www.sciencedirect.com/science/article/pii/S1045105603000307> Accessed: Nov. 18, 2019. doi: 10.1016/S1045-1056(03)00030-7.

HUTCHINGS, D. L. et al., Inhibition of antigen-induced and interleukin 2-induced proliferation of bovine peripheral blood leukocytes by inactivated bovine herpesvirus 1. Journal of Virology, v.64, n.9, p.4146-4151, 1990. Available from: <https:// www.ncbi.nlm.nih.gov/pmc/articles/PMC247878>. Accessed: Nov. 16, 2019.

IBGE. Pesquisa da Pecuária Municipal, 2015. Instituto Brasileiro de Geografia e Estatística. Available from: $<$ https://www.ibge.gov. br/estatisticas/economicas/agricultura-e-pecuaria/9107-producaoda-pecuaria-municipal.html edicao $=9108 \& \mathrm{t}=$ resultados $>$. Accessed: Nov. 20, 2019.

JUNQUEIRA, J. R. C. et al. Reproductive performance evaluation of a beef cattle herd naturally infected with the BoHV-1, BVDV and Leptospira hardjo. Semina Ciências Agrárias, v.27, n.3, p.471-480, 2006. Available from: <http://www.uel.br/revistas/uel/ index.php/semagrarias/article/download/2487/2112>. Accessed: Nov. 23, 2019.

KOPPERS-LALIC, D. et al. The UL41-encoded virion host shuttoff (vhs) protein and vhs-independent mechanisms are responsible for down-regulation of MHC class I molecules by bovine herpesvirus 1. Journal of General Virology, v.82, n.9, p.2071-2081, 2001. Available from: <https:/www.ncbi.nlm. nih.gov/pubmed/11514716>. Accessed: Nov. 20, 2019. doi: 10.1099/0022-1317-82-9-2071.

NISKANEN, R. et al. Effects of infection with bovine virus diarrhoea virus on health and reproductive performance in 213 dairy herds in one county in Sweden. Preventive Veterinary Medicine. v.23, n.4, p.229-237, 1995. Available from: <https:// www.sciencedirect.com/science/article/pii/016758779400437N>. Accessed: Jul. 05, 2020. doi: 10.1016/0167-5877(94)00437-N.

MARQUES, A. L. A. et al. Risk factors associated with Bovine Viral Diarrhea Virus (BVDV) infection in the semiarid of the state of Paraíba, in the northeast region of Brazil. Semina Ciências Agrárias, v.37, n.5, p.3095-3106, 2016. Available from: <http://www.uel.br/revistas/uel/index.php/ semagrarias/article/view/22493>. Accessed: Nov. 19, 2019. doi: 10.5433/1679-0359.2016v37n5p3095.

MINEO, T. W. P. et al. Distribution of antibodies against Neospora caninum, BVDV and BHV-1 among cows in Brazilian dairy herds with reproductive disorders. Revista Brasileira de Parasitologia Veterinária, v.15, n.4, p.188192, 2006. Available from: <https://www.ncbi.nlm.nih.gov/ pubmed/17196123>. Accessed: Nov. 19, 2019

MOERMAN, A. et al. Clinical consequences of a bovine virus diarrhoea virus infection in a dairy herd: a longitudinal study. Veterinary Quarterly, v.16, n.2, p.115-119, 1994. Available from: $<$ https://www.ncbi.nlm.nih.gov/pubmed/7985352>. Accessed: Nov. 19, 2019. doi: 10.1080/01652176.1994.9694430.

PATON, D. J. et al. Prevalence of antibodies to bovine virus diarrhoea virus and other viruses in bulk tank milk in England and Wales. Veterinary Record, v.142, n.15, p.385-391, 1998. Available from: $<$ https://www.ncbi.nlm.nih.gov/pubmed/9586130>. Accessed: Nov, 17, 2019. doi: 10.1136/vr.142.15.385.

POTGIETER, L. N. D. et al. Experimental production of bovine respiratory tract disease with viral diarrhea virus. American Journal Veterinary Research, v.45, n.8, p.15821585, 1984. Available from: <https://www.ncbi.nlm.nih.gov/ pubmed/6089623>. Accessed: Nov. 19, 2019.

RINALDI, L. et al. Survey of Neospora caninum and bovine herpes virus 1 coinfection in cattle. Parasitology Research, v.100, n.2, p.359-364, 2007. Available from: <https://www.ncbi.nlm.nih. gov/pubmed/17053931>. Accessed: Oct. 30, 2019. doi: 10.1007/ s00436-006-0335-4.

ROCHA, M. A. et al. Bovine Herpesvírus-1 in semen. Ciência Rural, v.29, n.2, p.373-380, 1999. Available from: <https://doi. org/10.1590/S0103-84781999000200032>. Accessed: Dec. 01, 2019. doi: 10.1590/S0103-84781999000200032.

ROCHA, M. A. et al. Survey of antibody against IBR on demanding sampling in Minas Gerais State, 1990-1999. Arquivo Brasileiro de Medicina Veterinária e Zootecnia, v.53, n.6, p.645-647, 2001. Available from: $<$ http://www.scielo.br/scielo.php?script=sci_artte xt\&pid=S0102-09352001000600003>. Accessed: Nov. 01, 2019. doi: 10.1590/S0102-09352001000600003.

RICHTER, V. et al. Mapping the global prevalence of bovine viral diarrhoea virus infection and its associates mitigation programmers. Veterinary Record, v.184, n.23, p.1-4, 2019. Available from: $<$ https://www.ncbi.nlm.nih.gov/pubmed/31040217>. Accessed: Dec. 01, 2019. doi: 10.1136/vr.105354.

SAMARA, S. I. et al. Occurence of the bovine viral diarrhoea in the south region of the state of Minas Gerais and northeast region of the state of São Paulo. Brazilian Journal of Veterinary and Animal Science, v.41, n.6, p.396-340, 2004. Available from:

Ciência Rural, v.51, n.12, 2021. 
$<$ http://www.scielo.br/pdf/bjvras/v41n6/25248.pdf>. Accessed: Mar. 05, 2020.

SANTOS, M. R. et al. Antibodies against Bovine herpesvirus 1 in dairy herds in the state of Espírito Santo, Brasil. Revista Ceres, v.61, n.2, p.280-283, 2014. Available from: <http:// www.scielo.br/scielo.php?script $=$ sci arttext\&pid $=$ S0034737X2014000200017>. Accessed: Oct. 30, 2019. doi: 10.1590/ S0034-737X2014000200017.

SCHERER, C. F. C. et al. A rapid virus-neutralization test for detection of antibodies against bovine viral diarrhea virus (BVDV) in milk. Pesquisa Veterinária Brasileira, v.22, n.2, p.45-50, 2002. Available from: $<\mathrm{http}$ ://www.scielo.br/scielo.php?script=sci arttext\&pid $=$ S0100-736X2002000200003 $>$. Accessed: Dec. 03, 2019. doi: 10.1590/S0100-736X2002000200003.

STAHL, K. et al. Bulk milk testing for antibody seroprevalences to BVDV and BHV-1 in a rural region of Peru. Preventive Veterinary Medicine, v.56, n.3, p.193-202, 2002. Available from: $<$ https://www.ncbi.nlm.nih.gov/pubmed/12441235>. Accessed: Oct. 31, 2019. doi: 10.1016/S0167-5877(02)00161-7.

STATHAM, J. M. et al. Reduction in daily milk yield associated with subclinical bovine herpesvirus 1 infection. Veterinary Record, v.177, n.13, p.339-344, 2015. Available from: <https:// veterinaryrecord.bmj.com/content/177/13/339>. Accessed: Nov. 16, 2019. doi: 10.1136/vr.103105.

STRAUB, O. C. Advances in BHV1 (IBR) research. Deutsche tierarztliche Wochenschrift, v.108, n.10, p.419 422, 2001. Available from: <https:/www.ncbi.nlm.nih.gov/ pubmed/11721589>. Accessed: Nov. 19, 2019.

TADESSE, T. et al. Seroprevalence of bovine viral diarrhea virus and its potential risk factors in dairy cattle of Jimma town, southwestern Ethiopia. Journal Dairy Veterinary Animal Research, v.8, n.1, p.11-17, 2019. Available from: <https://pdfs.semanticscholar. org/3b43/d2cdcf19ab8ac6426dc06352224af797953e.pdf $>$. Accessed: Dec. 02, 2019. doi: 10.15406/jdvar.2019.08.00235.

VAN ENGELENBURG, F. A. et al. Development of a rapid and sensitive polymerase chain reaction assay for detection of bovine herpesvirus type 1 in bovine semen. Journal of Clinical Microbiology, v.31, n.12, p.3129-3135, 1993. Available from: $<$ https://www.ncbi.nlm.nih.gov/pmc/articles/PMC266363>. Accessed: Dec. 02, 2019.

VÁSQUEZ, N. F. R. et al. Seroprevalence and risk factors of several bovine viral diseases in dary farms of San Pedro de los Milagros, Antioquia, Colombia. Ces Medicina Veterinaria y Zootecnia, v.11, n.1, p.15-25, 2016. Available from: <http:/www.scielo.org.co/ pdf/cmvz/v11n1/v11n1a02.pdf >. Accessed: Dec. 02, 2019.

VIEIRA, S. et al. Antibodies to bovine herpesvirus type 1 (BHV-1) in cattle sera from goiás, brazil. Ciência Animal Brasileira, v.4, n.2, p.131-137, 2003. Available from: <https://www.revistas.ufg. br/vet/article/view/306>. Accessed: Nov. 25, 2019.

WAAGE, S. Influence of new infection with bovine virus diarrhoea virus on udder health in Norwegian dairy cows. Preventive Veterinary Medicine, v.43, n.2, p.123-135, 2000. Available from: <https:// www.sciencedirect.com/science/article/pii/S0167587799000847>. Accessed: Dec. 05, 2019. doi: 10.1016/S0167-5877(99)00084-7.

WELLENBERG, G. J. et al. Viral infections and bovine mastitis: a review. Veterinary Microbiology, v.88, n.1, 2002. Available from: $<$ https://www.ncbi.nlm.nih.gov/pubmed/12119136>. Accessed: Dec. 05, 2019. doi: 10.1016/s0378-1135(02)00098-6.

WERNICKI, A. et al. Detection of the bovine viral diarrhea virus (BVDV) in young beef cattle in eastern and southeastern regions of Poland. Polish Journal of Veterinary Sciences, v.18, n.1, p.141-146, 2015. Available from: <https://www.ncbi.nlm.nih.gov/ pubmed/25928921>. Accessed: Oct. 29, 2019. doi: 10.1515/pjvs2015-0018. 